\title{
On some Chaetoceras of Japan. II.
}

\author{
By
}

Jiro Ikari.

With 13 figures in text.

The present work is a continuation of the previous one which was published under the title "On some Chaetoceras of Japan. I.", in this magazine, Vol. XL, No. 478, 1926. The species here treated are those which are either imperfectly known to Japan or are new to science. The number of species of this genus which I have examined from Japanese waters now amounts to no less than forty, and I expect to write another paper dealing with the same genus shortly.

\section{Chaetoceras danicum CLEVE.}

(Fig. 1, $a-c$.)

Ch. Wighami, VAN Heurck Synopsis, P1. LXXXII, Fig. 1. -Ch. boreale SchÜтT: 1893. p. 19, Fig. 5.-Do: 1896. p. 87, Fig. 144A.-ClEVE: 1897. p. 12.-MANGIN: 1912. p. 44, Fig. 30.-Hustedt: 1921. in Schmid's's Atlas, Taf. 342, Fig. 9.Akatsuka: 1914. p. 46, P1. 9, Fig. 7.-Pavillard: 1925, p. 42, Fig. 65 (after SchüтT).

Cells (12-16 $\mu$ broad) so itary or forming a very short filament

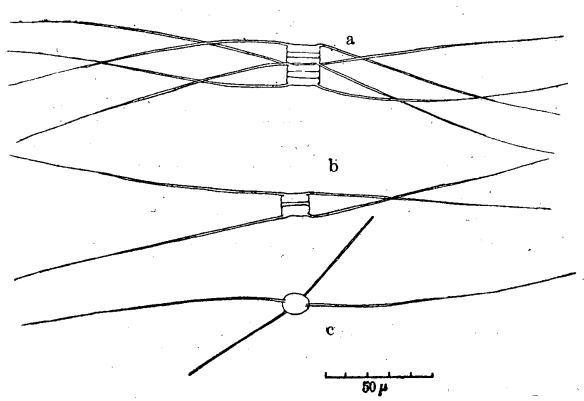

Fig. 1. Ch danicum. CrEVE. $a:$ two cells in chain, in a broad front, $b:$ a solitary cell, $c:$ a valve view of $b$. composed of $2-4$ cellis, with a very narrow girdle band; in a broad front, quadrate, at least less than I/ 3 of the cell-height; in a valve view, nearly circular, with thin straight setae, starting inside of the margin in a nearly horizontal direction, divergent in acute angles on both valves.

Chromatophores numerous ard small, and scattered in setae as well in the cells forming a chain, foramina always very small and slit-shaped.

Loc. Oshoro! Takashima, (AkATsuka. Ikari). 
Chaetoceras Okamurai IKARI. sp. nov.

(Fig. 2, a-e.)

Peragallia meridiana SchüтT, OKamuRa: 1907, p. 21 (131), P1. IV, Fig. 65.

Chain straight, not twisted, $(30-50 \mu$ broad). Cells in a front view, quadrangular with rounded angles, but sometimes much elongated. In the elongated cells of the chain there always appear many costations on their zonal parts and zig-zag sutures are present lengthwise on the

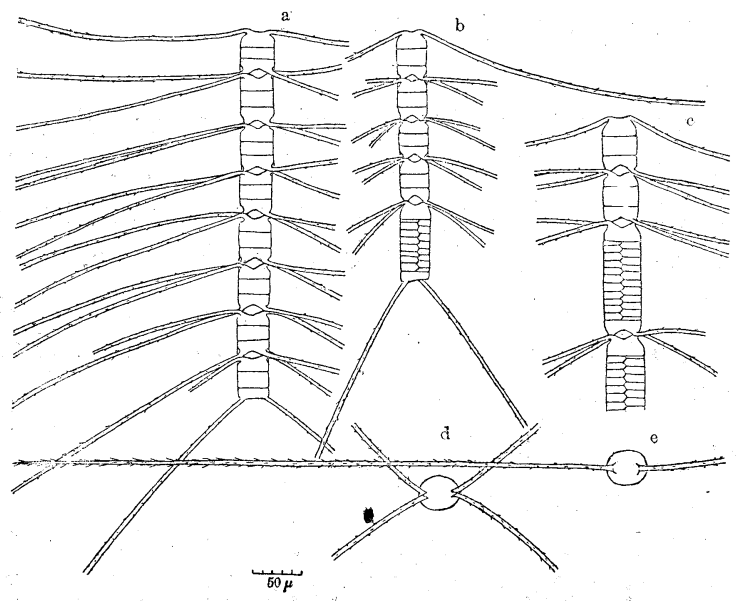

Fig. 2. Ch. Okamurai IkARI.

$a:$ an ordinary chain, $b:$ post-terminal cell showing many costations on its girdle band, $c$ : part of a chain, in which the two lower cells show manifest costations on the girdle, $d:$ a valve view, $e$ : the same view of the antero-terminal cell. median lines of these zones. Girdle band attains over $1 / 3$ of the cellheight or, sometimes, it is more than three times as long as the ordinary cell.

Valve convex and elevated to twolow cones leaving a shallow depression in the center of the valve. Foramina small and rather rhomboidal. Setae start direct from these cones and each then coalesces with that of the neighbouring cell within the lateral sides of the chain. The setae are all long, straight, and directed somewhat obliquely to the chain axis. They are adorned with spines which are more densely disposed on the distal parts. Cells in a valve view are almost circular. The antero-terminal setae run parallel to the sagittal axis, and setae in the middle are divergent at a right angle with each other. But the post-terminal setae run oblique to the chain axis and are divergent at nearly a right angle. also.

Chromatophores are smail, numerous, and are present in the setae

Loc. Seto! Prov. Tosa, Shirahama. (Okamura).

OKAMURA reported this form as a chain-forming example under the name of Peragallia meridiana ScHüTT. In doing this, he laid great stress upon the presence of the intercalary costations on the girdle band, which are well seen on that of Peragallia. However, these 
costations do not seem to be so important a character by which we can readily separate Peragallia from Chaetoceras, because I have often observed such costations or intercalary bands in several species of Chactoceras. In Phaeoceras, these structures may easily be seen in Ch. denticulatum LAUder, Ch. Eibenii Grun (cf. Irari: 1925. Bot. Mag. Tokyo, Bd. XXXIX, No. 458, p. 55, Fig. 2h.), and Ch. rostratum LAUDER. In'Hyalochaete, they have been met in $C h$. costatum PAviliard, Ch. pseudocurvisetum MANGIN, etc. According to my observation on Chaetoceras, such costations appear very frequently on the zonal regions of certain cells when these are by some cause strongly prolongated. FORTI (cf. 1912. p. 20.), in his phylogenetic table of the genera allied to Chaetoceras, placed the genus Peragallia between Attheya and Chactoceras. However, it is more natural and better, I think, to put Peragallia under Chaetoceras [see CLEVE (1907), PERAGALLO (1908), and ALBERT MANN (1907)].

AIBERT MANN has an opinion that both the two genera Peragallia and Bacteriastrum should be put under the genus Chaetoceras (1907, 1925) but in this I can not agree with him.

Again, on the phylogenetic lineage, I may insert Ch. bacteriastroides KARSTEN, between Chaetoceras and Bacteriastrum. Thus the phylogenetic order would be as follows:

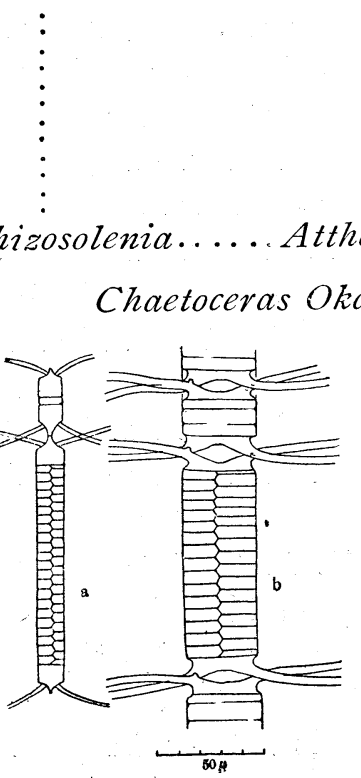

-Fig. 3. Examples of intercalary bands, $a: C h$. rostratum LAUDER, $b:$ Ch. denticulatum LAUDER.
Bacteriastrum

Ch. bacteriastrotdes KARSTHN.

\section{.}

. Chaetoceras (incl. Peragallia.)

(Fig. 4, a-c.)

The general character of this interesting form is the same as in the preceding species.

Cells form a very short chain (of 2-4 cells), but are often found solitary. The most prominent feature of this variety is the presence of four setae on each valve. Whether the species occurs solitary or is associated in chain, the free valves of the terminal cells are invariably furnished with four setae and they, in a valve view, are placed diagonally to the sagittal axis of the valves. The present form is apparently 
much like Ch. tetrachaeta EHRENBERG (cf. KüTzING: Sp. Algarum, p. 138. BRIGHTWELL: 1856.), but as there are no figures of this species published, I can not decide whether mecimen belongs to the species or not.

\section{Loc. Seto!}

\section{Chaetoceras indicum, KARSTEN.}

(Fig. 5, $a$ and b.) KARSTEN : 1907, p. 167, Taf. XLIII, Fig. 2.

Chain straight, not twisted, and composed of three cells $(20-30 \mu$ broad). Cell in a front view, quadrangular, or, frequently, much compressed; shorter than the breadth.

Valves similarly formed. Girdle band

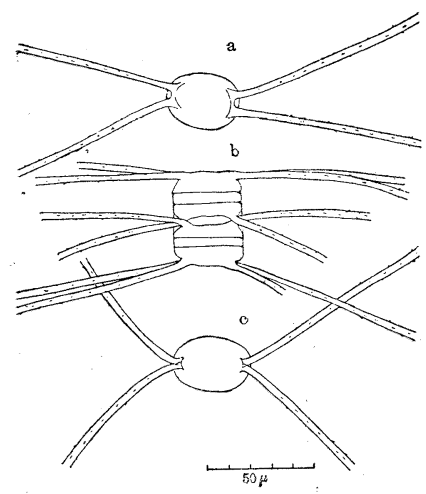

Fig. 4. Ch. Okamurai var. tetraseta IKARI.

$a$ : a valve view of anteroterminal cell, in which two setae insert within the margin of either side of the valve, $b$ : showing two cells in chain, $c$ : a valve view of the intermediate cell with setae. about $1 / 3$ of the mantle-height. Girdle sutures distinct. Valves convex with a distinct margin between valve surface and mantle. Setae long, spinose, and inserted in the sagittal plane at $2 / 3$ the distance from the center of the valve within the margin of the valve; they are provided with thick basal parts, running obliquely to the chain axis and then, making a broad arc, they are directed to one end of the chain, or, often, some bending directly downwards occurs. Valves excavated by thickening of the basal parts of setae, foramina thus being narrowly lanceolate. Cells in a valve view, elliptical and the setae divergent at an acute angle with each other. In a front view, there are always found small processes on the basal parts of setae like those in Ch. denticulatum LAUDER.

Chromatophores are smail and numerous and pass into the setae, the nucleus is situated in the middle of the cell in the resting condition.

Loc. Goza! Kushimoto! Seto!

The present species has a resemblance to $C h$. denticulatum LAUDER in having peculiar processes. However, it may easily be distinguished from the latter species by two conspicuous features, namely, the direction of the setae and the relative shortness of the mantles.

KARSTEN (1907) described and figured this species for the first time. In his figure the direction of the setae is much disturbed, though they are all directed to one end of the chain. Probably this is an abnormal form. 


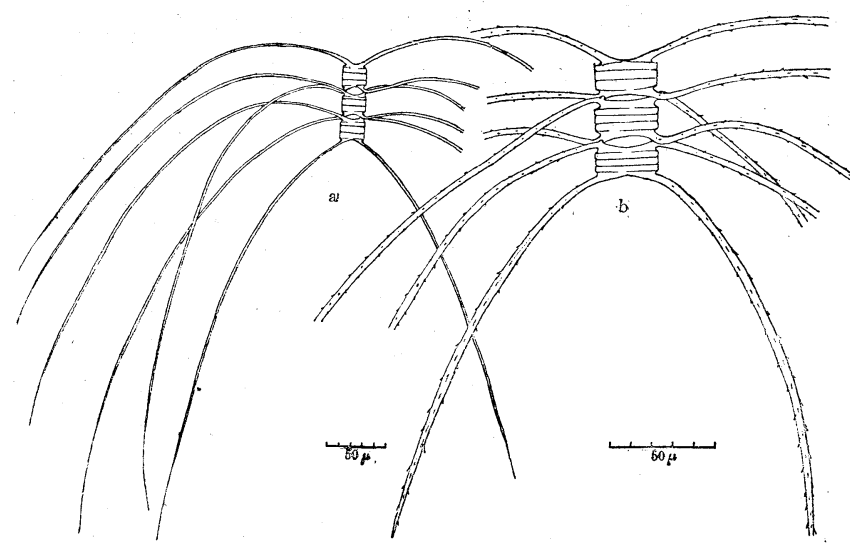

Fig. 5, Ch. indicurn KARSTEN. $a$ : a narrow chain, $b:$ an ordinary one.

In the same year, 1907. OkAMURA erecied a new species distinct from LAUDER's Ch. denticulatum under the name of $\mathrm{Ch}$. NANODENTICULATUM, which is characterized by the relative shortness of the mantle, etc. This nanodenticulatum is possibly the present species, although the distal portions of the setae are not shown in his figure.

\section{Chaetoceras sumatranum KARSTEN.}

(Fig. 6, $a$ and $b$.)

KARSTEN : 1907. p. 168 (388), Taf. XLV, Fig. 2, $2 a$.

Cells forming a straight (rarely slightly twisted) chain; $36-51 \mu$ broad. Frustules long. Girdle band high, over $1 / 3$ of the mantle and suture distinct. Valves convex with obtuse angles. Setae very long

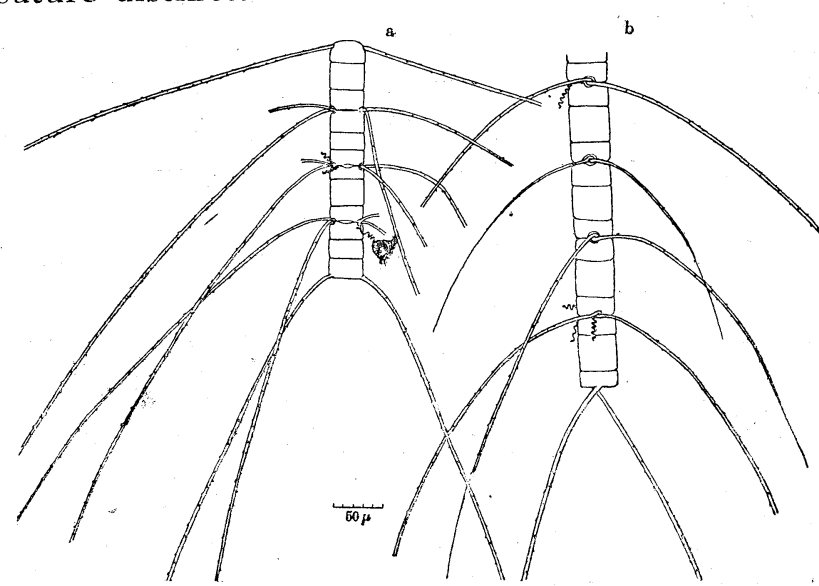

Fig, 6. Ch. sumatranum KARSTEN. $a$ : showing a chain in a broad front, $b$ : parts of a chain in a narrow front. with minute spinules densely disposed in the distal parts; at the basal thickenings they intersect themselves and run oblique to the chain axis, making obtuse angles with one another, gradlylau becoming curved, and all directed to the lower end of the chain. Starting point of the setae is nearly midway between the valve-center and its margin. The valves are more or less concave on account of the basal thickening of the setae, 
with foramen very small and of lanceolate form and sometimes even invisible. The antero-terminal valve of the chain is almost hemispherical or with a truncated apex, and the terminal setae are inserted a little inside the margin in an oblique direction; their distal portions are somewhat curved towards the other end of the chain. The post-

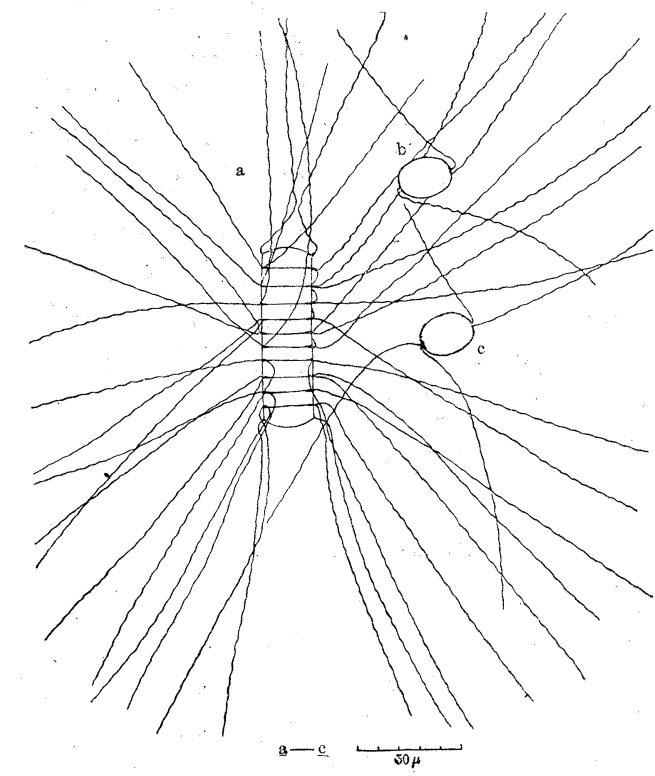

Fig. 7. Ch. compactum IKARI. $a$ : showing relative short chain, $b$ : a valve view of terminal cell, $c$ : a valve view of intermediate cell. terminal valves of the chain have a truncated or a flat surface and the setae issue directly from the margin of the valve, taking a direction oblique to the chain. Cells in a valve view, circular.

Chromatophores numerous, small, somewhat Bacillus-shaped, present in the setae also, the resting nucleus is somewhat ellipsoidal and situated in the center of the cell.

Loc. Takashima! Goza! Kushimoto! Seto! Miyazu! (Prov. Tango).

The present species occurs in June and July collections of Seto, associated with Vorticella oceanica ZACHARIAS; but, it is much rarer than Chaetoceras coarctatum LAUDER.

\section{Chaetoceras compactum IKARI. sp. nov.}

(Fig. 7, $a-c$. )

This form seems to represent another new species. It occured in July collections of Seto, etc.

Cells very flat, cylindrical, and arranged in a short straight chain; 18-30 $\mu$ broad. The cells of the chain are associated so closely together that there is no space left for foramina, except a very small slit on either side of the cell. Valves flat, except the free ends of the terminal cell, which show a conspicuous dome-like convexity. Setae very long (more than $300 \mu$.) and rather straight, with strong undulations; they are directed obliquely to both extremities of the chain, but some run nearly perpendicular to the chain. Cells in a valve view almost circular, setae diverging at a right angle. Terminal setae run almosi 
parallel to the chain axis. There is only one chromatophore. The resting spore is unknown.

\section{Loc. Seto! Miyazu!}

The present species is closely allied to Ch. crinitum ScHüT'T, but this is well distinguished from the latter by the following features: 1 , there are strong undulations on the setae; in closer examination many beads-like spots are spirally disposed along the setae. 2, setae start at the margin of the valve.

\section{Chaetoceras laciniosum Schï̈T'T.}

(Fig. 8, a.)

SchüтT: 1895. p. 38, Fig. 5, $a-$ c.-CLEvE: 1894. p. 14, Taf. 2, Fig. 2, $a-b .-$ GRAN: 1897. p. 17, Taf. I, Figs. 4, 5, 6 and 7.Do: 1906. p. 82, Fig. 100, a-c.-MEUNIER: 1910. p. 235, P1. XXVI, Figs. 24-31.-YENDO and GRAN: 1914. p. 18, Fig. 11.HustedT: 1921. in Schmid's Atlas, Taf. 338, Figs. 2 and 3. -PAVIllard: 1925. p. 48, Fig. 75 (after GraN).

Cells forming a straight chain (16-20 $\mu$ broad), and in a broad front,

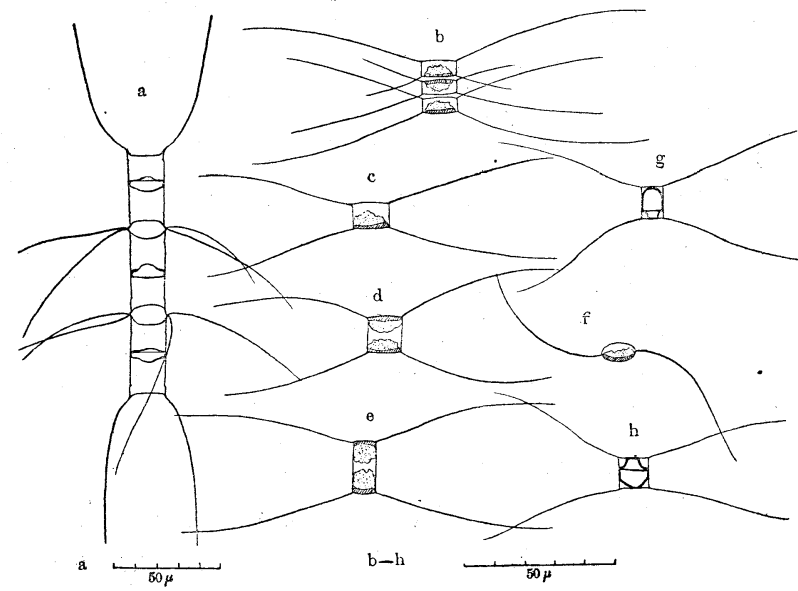

Fig. 8. Ch. laciniosum SchüTr, and Ch. subsalsum LEMMERMANN.

$a$ : spores-bearing chain of $C h$. laciniosum, $b-h$ : Ch. subsalsum,

$b$ : showing a chain of three cells, $c-e$ : solitary cells in various

shape, $f$ : a valve view of one solitary cell, $g . h$ : solitary cells bearing resting spores within them. rectangular to quadrangular, with projecting angles. Valves flat, being occasionally slightly convex in the middle.

Foramina large, broadl elliptic or quadrangular with round angles. Setae thin, with their basal parts almost parallel to the chain axis; they all curve towards one end of the chain. Terminal setae are rather well differentiated, sometimes with minute punctuations, and are disposed parallel or more or less divergent, while, in a narrow front, they are divergent at about a right angle. Chromatophores: two, forming a large plate disposed close to each valve. Resting 
spores formed near the middle of the cells, a little closer to one valve of the cell; both valves smooth, the primary valve arcuate, and the secondary one flat or with a slight elevation in the middle.

Loc. Oshoro! Takashima! Ajiro! (Prov. Inaba.), Naha! (Okinawaken.), Volcano Bay. Misumi. (YENDo).

The present form has a close resemblance to Ch. distans $\mathrm{C}_{\mathrm{LEVE}}$, so that they are apt to be confused. GRAN and Yendo (1914) have pointed out that the suture lines of the girdle bands of $C h$. distans are convex towards the foramina, while the same in Ch. laciniosum ScHüT'T are parallel. However, according to my observation, this is not always true, but the basal part of the present species are more or less shorter than those of $C h$. distans. Moreover, the terminal setae in a narrow front are divergent with each other, while in Ch. distans they are placed in a plane including the sagittal axis.

\section{Chactoceras subsalsum LEMMERMANN.}

(Fig. 8, b-h.)

LEMMERMANN : 1902. p. 141, Fig. 16.-Ch. Zachariasi HoNIGMANN: 1910 . p. 72, Taf. I, $a$ and $d$-OSTENFELD: 1912. p. 4, Fig. 5-10.-RoupperT: 1913. p. 299, Taf.-Ch. Thienemanni HuSTEDT: 1925. p: 104, Taf. (p. 121), Fig. 16-12.-Kolde: 1927. p. 34, Taf. II, Fig. 28-31.

Cells solitary or 2, 3, rarely 4 , together. Frustules in a front view, quadrangular; in a valve view elliptical. Valves slightly convex. The breadth of the ceil $7-15 \mu$, and the height $6-19 \mu$. Setae thin and delicate. They in a front view, start in a direction oblique to the chain axis, are more or less arched in the proximal part, and nearly parallel or slightly diverging in the distal part. In a valve view, a pair of setae on the same valve shows sigmoid curvature, another pair on the other side shows a similar appearance, but as a matter of fact, start from angles parallel to the sagittal axis of the cell, and then both gradually bend towards the transverse axis. Setae in a chain intersect with one another at the point which is somewhat apart from the sides of the chain. Foramina, if present, linear, but narrowing slightly in the middle.

Resting spore is formed in the middle of the parent cell; the primary valve is arcuate or hemispherical; the secondary one is very characteristic, and cupliform. Chromatophore, one large plate (two in the cell preparing for division) appearing partly on valve side, partly in front.

Loc. Tainan! (Formosa). A brackish-water form.

The material was kindly sent to me by Mr. WATANABri who 
collected it from a Sabahi ${ }^{1)}$ culture-pond of the Tainan Piscicultural Station in Formosa. According to his kind information, the breeding pond is $3300 \mathrm{sq} . \mathrm{m}$. in size, and $30 \mathrm{~cm}$. deep. Yearly, at the end of April or at the beginning of May, the sea water is introduced through a narrow channel into this pond and then the young of the fish are put into the pond. 'The salinity of the pond water is much varied according to the weather. The most luxuriant period for this minute diatom species occurs during April-May, when the pond water is between $1.0038-1.0000$ in sp.gr.

\section{Chaetoceras Pavillardii IKARI sp. nov.}

(Fig. 9, $a-d$.)

PAVILLARD: 1925. p. 52, Endocystes.

Cells less than ten forming a short straight chain (12-17 $\mu$, sometimes up to $37 \mu$, broad). Frustules in a front view, quadrangular, with sharp projecting angles. Valves concave or sometimes flat. Foramina oval-lanceolate. Girdle band rather broad and exceeding half the cell height. Suture distinct.

Chromatophores, one in front, sometimes two close to the valve, one on either side of the nucleus. Setae thin, issuing from the angles of the valves, crossing with each other, leaving short basal parts and diverging at an obtuse angle. Resting spores situated usually near the middle of the parent cells; the primary valve greatly vaulted with one or two, sometimes five, spines on the summit, besides the pallisade

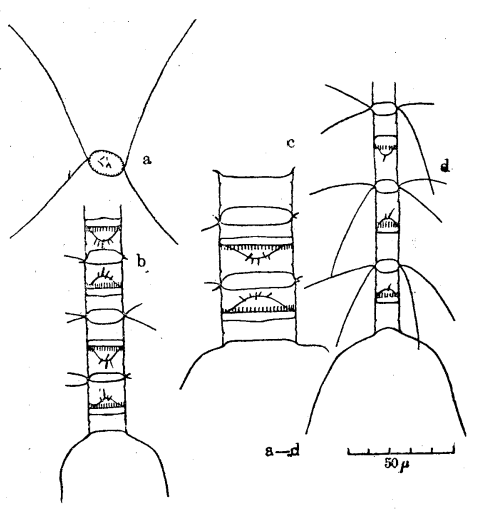

Fig. 9. Ch. Pavillardii IKaRI. apiculi along the margin. Secondary valve nearly flat and smooth.

PAVILLARD in his paper shows isolated resting spores obtained from the intestinal contents of Salpae, and from the nature of the spores he has inferred that they are akin to that of $C h$. diadema on the one hand, and to those of Ch. coronatum and hispidum on the other.

Fortunately, I found species with spores first in my collections from Seto (Feb.-March, 1924 and 1926) and after-

1) A fish (milk fish) belonging to the Clupeidae (Chanos chanos Forsk.), and called "Sabahi" in Chinese, abundantly cultivated in the southern parts of Formosa. Although a sea fish, it is able to accommodate itself easily to brackish or even fresh water. 
wards in those from Takashima, Hokkaido and Ajiro, Prov. Inaba.

The character of the spores is coincident largely with those of the spores of Biscay Bay. However, I have often found two or three accessory apiculi, besides one or two distinct spines on the primary valve shown in PAVILLARD's illustrations. Since the vegetative cells are very like those of $C h$. hispidum, it is difficult to distinguish the two species unless spores are obtained.

Loc. Takashima! Seto! Ajiro!

\section{Chaetoceras nipponica IKARI sp. nov.}

(Fig. 10, $a-d$.

Chain straight, but twisted at an angle of about $180^{\circ}$ along the chain axis when composed of about twenty-five cells. Frustules in a broad front quadrangular with somewhat pointed angles which are contact directly with the angles of adjacent frustules. The height of the girdle band exceeds not less than 1/3 that of the cell. Suture well-defined, foramina narrow and linear with a slight constriction in the middle. Valves are flat but show a slight convexity in the middle where they sometimes touch one another and the foramen is thus divided in the middle two small lateral portions. In a narrow front, two consecutive cells in a chain have the same mother band and their valve surfaces are more convex. Setae thin, curved and running in all

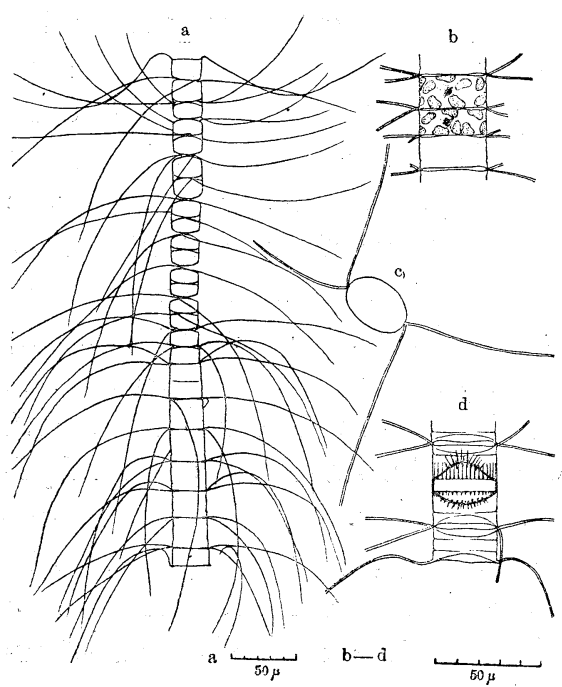

Fig. 10. Ch. nipponica IKARI.

$a:$ a chàin, $b:$ chromatophores within the cells, $c:$ a valve view, $d:$ part of a spore-bearing chain. directions, perpendicular, parallel, or oblique to the chain, while, their distal parts run out towards both extremities of the chain. Terminal setae not differentiated, but having a characteristic curvature; they start at first obliquely inwards of the chain, then gradually recurve to the extremities. Cells in a valve view, broadly elliptical, and one pair of setae are disposed nearly parallel to the sagittal axis, while another pair are placed perpendicular to it, the members of both pairs making a right angle with each other.

Resting spores formed in the middle of the mother frustures, with spines and pallisade apiculi. The 
primary valve less vaulted than the secondary but with many more spines on the surface; the secondary valve rather humped, with spines limited on the summit. The spines and pallisade apiculi rather longer and stouter than those of the primary. Chromatophores about ten in a cell and all flat or disc-shaped.

This form seems to represent a new species which is closely akin to Ch. tortissimum GRAN, and also to Ch. crinitum ScHUT'T. There is only one chromatophore in these species, however; in this respect the present species is sharply distinguished from them both.

Loc. Goza! Seto! Sakate! (in the Setonaikai).

Chaetoceras siamense OSTENFELD.

(Fig. 11. $a-e$.)

Ch. Ralfs var. LAUDER: 1864. p. 78, Pl. VIII, Fig. 3.-OSTENFELD: 1902. p. 21 (239), Fig. 17.-Ch. misumense Gran and YENDO: 1914. p. 14, Fig. 7, $a-c$.

Cells forming a long straight chain, 25-60 $\mu$ broad; chain often compoesd of twenty or more cells. Foramina narrowly lanceolate, with two peculiar depressions in the middle of each valve. Girdle band at least $1 / 3$ of the cell height. Valves broadly elliptical. Setae all alike, rather stout and undulated; they are disposed in a valve view at about right angles with one another. Terminal setae nearly

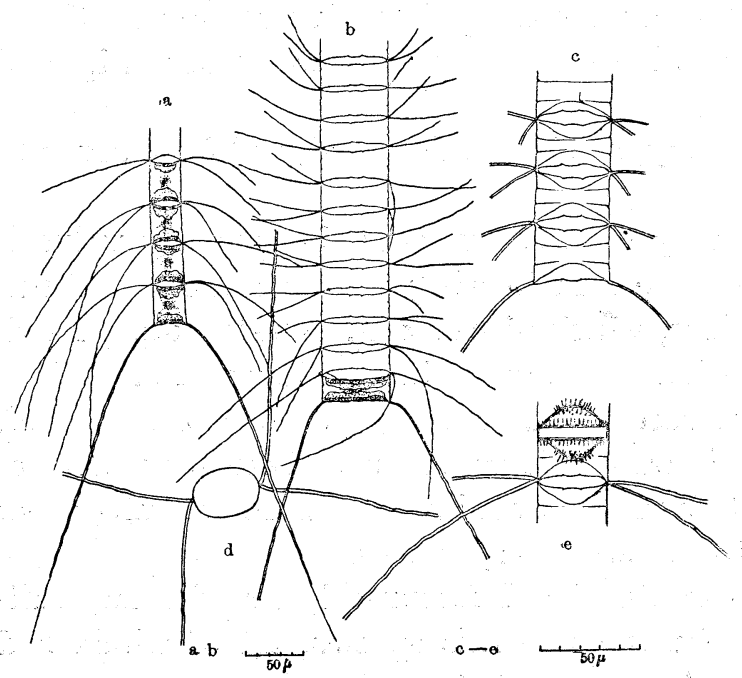

Fig. 11. Ch. siamense OSTENFELD. $a$ : shows part of a narrow chain, $b-c$ : showing broad chains, $d:$ a valve view, $e$ : resting spore. parallel to the chain axis or somewhat divergent from each other. Resting spores formed at about the middle of the mother cells, with pallisade apiculi on the margins of both valves. The primary valve arcuate with numerous spines ove- its surface; the secondary one nearly similar to the former, but rather humped and the spines limited on the summit.

Chromatophores two, situated close to the valve. 
I have often met a form in a collection of mine which has a similarity, to $C h$. siamense OSTENFELD, on one hand, and to $C h$. misumense GRAN et YFindo on the other.

The original diagnosis of both these species, however, is rather incomplete, and it is difficult to tell whether they are identical or not. It is quite possible that, if the nature of spores and the number of chromatophores were known, they would be revealed to be one and the same species.

Loc. Goza! Kushimoto! Seto!, Misumi (GRAN and YENDo).

\section{Chaetoceras mitra (BAIL.) CLEVE.}

(Fig. 12, $a-e$.)

Dicladia Groenlandicus CLEVE: 1873. p. 12, Taf. 2, Fig. 10, $a-b .-D$. mitra BAILEY : VAN HEURCK Synopsis, 1880-81. P1. CVI, Figs. 12, 13.-Ch. mitra (BAIL.) CLEVE: 1896. p. 8, P1. 2, Fig. 1, $a-c$ and 2.-GraN: 1106. p. 75, Fig. 89, $a-b .-C h$. mitra (BAIl.) GRAN, AkATSUKA: 1914, p. 55, P1. 12, Fig. 6.MEUNIER: 1910. p. 223, Pl. XXV, Fig. 1-7.-HUSTEDT: 1920. Taf. 321, Fig. 15.

Chain straight, multicellular (28-48 $\mu$ broad). Foramina narrow, pandriform to narrow elliptical. Cells in a front view, quadrangular, with slightly projecting angles. Valves concave, oblong in a valve view, and lanceolate. Setae rather thin, in a valve view, divergent almost in a right angle. Terminal setae rather stouter than the others, with minute punctuations and obsolete transverse striations in ignited specimens.

Chromatophores are many, small and flattened, and from seven to twelve in each cell.

Resting spores, with very different valves; the primary valve is elevated into two large cones, each bearing a solid stem and much ramified branchlets, or spines, which fill the cell. On the other hand, the secondary one is smooth and vaulted, with two low peaks.

The species was first recognized in the Japanese flora by Prof. AkATSUKa (1914), who discovered it in the neighbouring waters of Takashima, Hokkaido. Spores delineated by him were not full-grown ones, so that they did not have secondary valves.

In the course of my examination I fortunately found many fuligrown spores within the frustules of this species, all of which had complete secondary valves. The spores indicated in the papers of GRAN (1906), Meunier (1910), and Husthit (1920) are all well developed ones; the secondary valves have a form similar to one another; they 
are smooth, equally vaulted, but without such an undulated surface as shown in my figures. The undulated surface on closer examination, is composed of two low peaks upon the hemisphere but it has a somewhat oblique disposition on either side of the sagittal axis of the cell. Spores having a shape to this are already known to occur in the fossil diatoms (cf. VAn Heurck Synopsis, P1. CVI, Fig. 14., Brightweli, 1856. Pl. VII, Fig. 53-60., TEMPERE et BRUn: 1889. p. 69). More recently, PANTOCSEK (1905) reported such spores from Japan in Diclaidia capreolus EHRENBERG, which is known from marine fossil deposits from Tukuro Id. Hokkaido, and Dicladia japonica PANT. known from the Tertiary strata near Wembetsu, Hokkaido. CASTRACANE's figures of Ch. dicladia CASTR. (1886. p. 82, P1. VIII, Fig. 1, and P1.
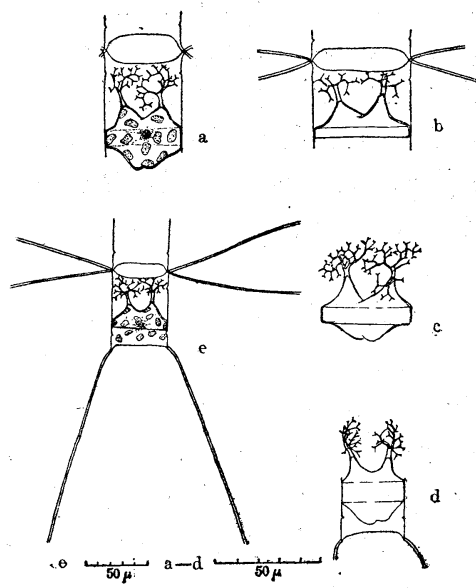

Fig. 12. Ch. mitra (BAIL.) CleVE. XIX, Figs. 7, 8.), show another kind of similar spores, but the vegetative cells of Ch. dicladia are entirely different from those of the present species.

The spores of Ch. Lorenzianum GRUN., were first recorded by $\mathrm{CLEVE}^{1)}$ in 1897. Next, Peragalio (1905) noticed the occurrence of the spores of $C h$. LORENZIANUM from the waters of the Mediterranean. OKamura (1911) showed some figures of spore-bearing cells of the same species from Tateyama and Goza on the Pacific side of Japan. These spores has a close resemblance to those of the present species, and have evidently often been confused, although GRAN in his paper shows the difference as follows: "Dauersporen ähnlich denjenigen von Ch. mitra, aber mit viel niedrigen Fortsätzen auf der Primärschale."

The vegetative cells of $C h$. Lorenzianum GRuN, Ch. decipiens CLFVE, and $C h$. mitra are very closely allied, and very often they are mixed together but the setae or awns of $C h$. Lorenzianum, even in the water-preparations, are furnished with manifest punctuations. In the other two species, on the contrary, such punctuations, even if present, are very obsolate in the ignited materials. The present species differs from Ch. decipiens CLEVE. in the three following points which MEUNIE:R has well indicated: 1 , the mode of intersection of setae; 2 , divergency of the crossing setae; and, 3 , the contour of cells in a valve view

1) In the preceding year he had removed Dicladia mitra and allied species to the genus Chaetoceras. 
Loc. Oshoro! Takashima. (AkaTsuka. IkARI.)

\section{Chaetsceras teres $\mathrm{CLEVE}_{\mathrm{E}}$.}

(Fig. 13, a.)

CleVE: 1896, p. 30, P1. Fig. 7, a-c.-Do: 1897. p. 22, P1. II, Fig. 10.-GRAN : 1897. p. 13, Figs. 35, 36.-Do: 1906, p. 76, Fig. 91, $a-b .-$ PFRAGAllo: 1908. p. 486, P1. CXXXIV, Fig. 1.-MEUNIER: 1910. p. 226, P1. XXV, Figs. 8, 9, 10, and 11.MANGIN: 1912. p. 52, Fig. 40, II.-IKARI: 1921. pp. 222-227, P1. V, Fig. 7.

The present species is hard to distinguish from Ch. Weissflogii Schu'T, and also from the next species, Ch. pacificum IKARI except by the resting spores, so that we have often confused them with one another. Chaetoceras teres $\mathrm{C}_{\mathrm{LEVE}}$ has been known as an arctic species, while $C h$. Weissflogii ScHüT'T as a species occurring in warmer seas. In the neighbouring waters of Takashima, Hokkaido, the three above-mentioned species occur. On the Japanese coast Ch. teres is limited to the more northern area, while the other two have a broader distribution.

The resting spores of this species are formed in the middle portion of the mother cells. Both valves are vaulted, the secondary one being usually less vaulted than the primary. The primary valve has a short cylindrical girdle band which closely fits to the mother mantle; besides, it has a crown of punctuations on its margin, as was well illustrated by Gran (cf. 1897. P1. III, Fig. 36.), but the punctuations are sometimes very obscure. The secondary valve has a row of fine hairs (ca. $40 \mu$ long.) on its margin. Such spores were well illustrated by MANGIN (1912). CLEVE (1896) in his paper has shown an isolated spore which he attributes with some hesitation to $C h$. commutatus. This spore belongs, without doubt, to the present species.

Loc. Oshoro! Takashima! Volcano Bay (Yendo).

\section{Chaetoceras pacificum IKARI $s p$. nov.}

(Fig. 13, $b$ and c.)

In the character of the vegetative cells the present species is very much like $C h$. teres $\mathrm{C}_{\text {LEVE }}$ and $C h$. Weissflogii ScHÜTT; but it can readily be distinguished from either of these two species by its resting spore. The resting spore of this form is characteristic; the primary valve is nipple-shaped or greatly humped, with $2-5$ stout, somewhat incurved, spines on its summit, while the secondary one is always flat and often with a slight convexity in the middle. Moreover, a row of 


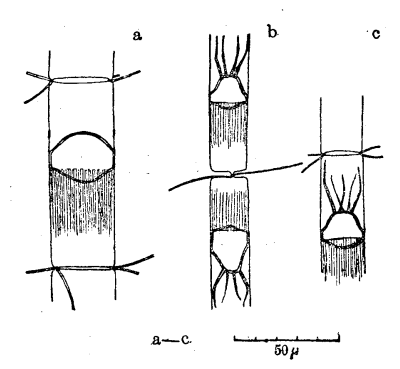

Fig. 13. Spores of two species. $a:$ Ch. teres CIEVE; $b-c$ : Ch. pacificum IKARI. long fine hairs is present on its margin. This spore is not unlike that of Ch. Weissflogii Schu'T' ; but there are no pallisade apiculi on the margin of the primary valve; besides, the strong spines are $2-5$ in number and are limited on the summit of the valve, the spines being fewer and stouter than those of Ch. Weissflogii. In these points the present species differs from $C h$. Weissflogii on one hand and from $C h$. teres on the other.

Loc. Takashima! Seto!

In conclusion, I wish to express here my sincere thanks to Prof. TAKU KOMAI. for courtesies bestowed on me in various way.

Feb. 15. 1928.

\section{Seto Marine Biological Laboratory, Setokanayama, Wakayama-ken.}

\section{LITERATURE CONSULTED.}

(That already cited in my previous paper is omitted).

1907. ALBERT MANN. Report on the Diatom of the Albatross Voyages in the Pacific Ocean, 1888-1904.

1925. Marine Diatoms of the Philippine Islands.

1851. BAILEY, J. W., Miscroscopical examination of Soundings, made by the.U.S. Coast Survey of the Atlantic coast of the United States.

1856. BRIGHTWELI, T., On the filamentous, long-horned Diatomaceae, with a description of two new species.

1873. Cleve, P. T., On Diatoms from Arctic Sea.

1894. - II. Planktonundersökningar: Cilioflagellata och Diatomacéer.

1896. Diatoms from Baffins Bay and Davis Strait.

1896. - V. Planktonundersökningar: Vegetabiliskt Plankton.

1897. A treatise of the phytoplankton of the Atlantic and its tributaries and on the periodical changes of the plankton of Skagerak.

1912. FORTI, A., Contribuzioni Diatomologiche-XII. Metodo di classificazione delle Bacillariee Immobili fondato sull'affinità morfologica dei frustoli ed in relaxione con l'evoluzione dell'auxospora.

1910. Hans Honigmann. Beiträge zur Kenntniss des Süsswasserplanktons.

1925. HuSTEDT, FR., Bacillariales aus den Salzgewässern bei Oldesloe in Holstein.

1927. KoLBE, R. W., Zur Okologie, Morphologie und Systematik der BrachwasserDiatomeen.

1864. LAUDER, H. C., Remarks on the marine Diatomaceae found at Hong Kong with descriptions of new species.

1903. LEMmermann, E., Das Plankton schwedischer Gewässer.

1910. Meunier, A., Microplankon des Mers de Barents et de Kara. 
1912. OSTENFELD, C. H., A Revision of the marine species of Chaetoceras EHBG. Sect. Simplicia OsTenf.

1905. PANTOCSEK, J., Beiträge zur Kenntniss der fossilen Bacillarien Ungarns. III. Theil.

1897-1908. Pergalilo, M. et H., Diatomées marines de France et des Districts maritimes voisins.

1913. RoUPPERT, K., Ueber zwei Plankton-Diatomeen (Chaetoceros Zachariasi und Attheya Zachariasi).

1893. Scrürrr, FR., Das Pflanzenleben der Hochsee.

1896. — Bacillariales (Engler u. Prantl: Natürliche. Pflanzenfamilien. I. Teil. Abt. 1b..

1889. TEMPERE et BrUn. Diatomées Fossiles du Japon.

1915. Tempere et Peragalio. Diatomées du monde Entier, 2e Edition.

\section{あやめ屬植物ノ細胞學的研究（豫報）}

風尾なつ

NATSU KAZAO: Cytological Studies on Iris (Preliminary Note).

Iris 屬八普ヨリ觀賞用植物トシテ栽培サレ其種及變種カ頗ル多イ。併シ細胞學的 方面ノ研究八此較的二少ク僅カ = STRASBURGER 氏 (1900) J I. germanica, I. pseudacorus 及ビ I. squalens ト三宅氏 (1905) ， I. spuria, I. florentina, I. pallida 等= 就テ研究ガアル計リデアル1)。コレ等ノ研究ニヨルト以上ノ諸種入皆 ハプロイド染 色體數八 12 ダトイフコトデアル。

私八此ノ春カラ田原敉授指導ノ下 $=$ 本邦産種々 I I ris = 就テ細胞學的研究 7 行七 今向繼續中デアルガ今日迄二得夕結果ヨ次二豫報トシテ報告ショウ。

材料八主トシテ仙臺市東北帝國大學生物學敎室植物園及ビ市內ノ庭園 =栽培サレ テアルモノラ用ヒタ。

花粉母細胞 つ固定=八 FLEMMING 强液及ビ弱液、BOUIN 液及ビ CARNOY 液等

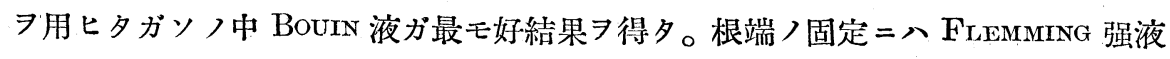

1) TISCHLER (1927), Tabulae Biologicae. 